\title{
Mahalle ve Konut Tipolojisi Açısından Bahçesaray (1650-1675) ${ }^{*}$
}

\author{
Dr. Öğr. Üyesi Fırat Yaşa \\ Düzce Üniversitesi Fen-Edebiyat Fakültesi \\ Tarih Bölümü \\ yasafirat@gmail.com
}

Öz

Osmanlı tarih araştırmalarında mahalle, mahalleyi oluşturan yapılar ve ev tipolojisi üzerine birçok çalışma bulunmaktadır. Bu çalışmalar ya mekânsal açıdan mahalleyi değerlendirmiş ya da normatif kuralların denetleyici misyonunu üstlenen yerel görevliler üzerinden ele alınmıştır. Tipik Türk-Osmanlı mahallesinin yapısal özellikleri ve konut tipolojisi bölgesel çapta detaylı çalışılmasına rağmen Kırım şehirleri açısından oldukça sınırlı bilgiye sahibiz. Bahçesaray mahalleleri üzerine herhangi bir çalışmanın bulunmaması söz konusu konunun ele alınmasını gerekli kılmıştır. Bu makalenin amacı Osmanlı ve Kırım mahallelerinin hangi açılardan benzerlikler ve farklılıklar içerdiğini ortaya koymaktır. Aynı zamanda mahalleleri oluşturan temel yapılar arasında yer alan konutların yapısal özellikleri de inceleme konusu olacaktır. Edraw-Max isimli bir mimarlık programına kadı sicillerinden edinilen veriler işlenerek kimin kime komşu olduğu, yapıların düzenli bir şekilde mi yoksa gelişigüzel şekilde mi imar edildiği tespit edilmeye çalışılacaktır.

Anahtar Kelimeler: Kırım, Bahçesaray, Mahalle, Konut, Edraw-Max.

\section{The Neighbourhood and House Typology of Bakhchisaray (1650-1675)}

\section{Abstract}

There have been many studies on neighbourhood and neighbourhood buildings and house typology in Ottoman historical research. Such studies have either assessed the urban quarters in terms of spatiality or focused on local officials who controlled the application of normative codes. Although the structural characteristics of the typical Turkish-Ottoman neighbourhood and house typology in various regions have been studied in detail, we have very limited knowledge of Crimean cities. The lack of study of Bakhchisaray neighbourhoods makes it necessary to research the topic. The purpose of this article is to reveal the similarities and differences that exist between the Ottoman and Crimean neighbourhoods. The structural characteristics of the basic houses constituting the neighbourhood are also examined. By entering the data obtained from the Sharia court registers into the architectural program called Edraw-Max, we attempt to identify neighbours and to determine whether a house or another building was constructed in a regular or haphazard manner.

Keywords: Crimea, Bakhchisaray, neighbourhood, house, Edraw-Max.

\footnotetext{
* Bu makale, Avrupa ve Balkan Araştırmaları sahasında Türk Tarih Kurumu tarafından desteklenen ve Prof. Dr. Yücel Öztürk danışmanlığında tamamlanan Bahçesaray (1650-1675) başlıklı Doktora tezinden üretilmiştir. 


\section{GİRIŞ}

Osmanlı şehri özelinde birçok İslami şehir çalışmalarının dayanak noktası olarak Max Weber'in çalışmaları gösterilir (Weber 2010). Öyle ki Weber'in 20. yüzyılın başlarında ileri sürdüğü "şehir" tanımına İslam dünyasındaki şehirleri dahil etmemesi gerek Türkiye gerekse de dünyada ciddi tepkiler almasına neden olmuş ve "İslam" şehrinin varlığını kanitlamak amaciyla bazı çalışmalar ortaya konulmuştur (Özvar-Bilgin 2008; EdhemGolfmann-Masters 2012; Leeuwen 2012). Bu çalı̧̧malardan biri de Doğan Kuban'a aittir. Kuban bir İslam şehrinin en belirgin özelliğini fiziki açıdan şehrin üniteler halinde mahallelere bölünmesi olarak ifade etmektedir (Kuban 1978: 54).

Gerçekten de şehir, alışverişin yapıldığı pazar, çarşı gibi yapılar ve bu yapılar topluluğunun meydana gelmesinin ana etkeni olan mahallelerin varlı̆g 1 ile mümkündür (Koç 2005: 169). Birbirini tanıyan insanların birlikte yaşadığı, aynı cami ya da kilisede ibadet ettiği ve hatta toplum tarafından belirlenmiş normlar ile birbirinin hareketlerinden sorumlu olduğu mekân mahalle olarak bilinmektedir (Ergenç 1984: 69).

Kırım şehirlerinin diğer Osmanlı şehirleriyle büyük ölçüde aynı yapılara sahip olduğu kadı sicillerinden anlaşılmaktadır. Osmanlı şehirlerindeki etnik yapıya göre ayrışmış mahalle düzeni, Kırım'ın, Bahçesaray başta olmak üzere, tüm şehirlerinde kendini göstermektedir. Aynı dine mensup kişiler daha rahat hareket edebilmek, kendine yakın olanlarla bir arada bulunmak amacıyla doğal bir ayrı̧̧manın içinde mahallelere bölünmüşlerdir (Ortaylı 2008: 281). Şehrin nüfusunun ve dışarıdan gelenlerin artması yeni mahallelerin kurulmasını gerekli kılmış ve zamanla mahalleler sadece etnik yapıya göre değil, aynı iş kolundaki zanaatkârların oturduğu yerler olarak da ayrışmıştır.

Genellikle birbirini tanıyan bireyler olarak tanımladığımız kişilerin en azından 17. yüzyıl Kırım toplumunda tek tek bireyler olarak değil aşiretler, oymaklar şeklinde ayrışıp mahalleleri kurdukları görülmektedir. Aşirete veya bir boya mensup olanların başlarında dini liderler vardır. Böylece mahalle fiziki bir mekân olmanın ötesinde birbirinin faaliyetlerinden sorumlu bireylerin varlığı ile de toplumsal kontrolü sağlayan bir yapıya bürünmektedir (Abacı 2005: 105; Çetin 2016: 132; Kuban 1978: 62).

Kırım hanı Mengli Giray Han'ın 1503 tarihinde yaptırdığı saraya taşınması (KançalFerrari 2005: 61; Kançal-Ferrari 1997: 521) ile sarayın etrafına yerleşilmeye başlanmış ve şehrin mahalleleri ayrışmıştır. Zamanla Bahçesaray adını alan şehirde Müslümanlar, Yahudiler, Ermeniler, Çingeneler ve diğer dini ve etnik gruplar kendi mahallelerini kurmuşlardır. Böylelikle ihtiyaçlara binaen yeni bir şehir tarih sahnesinde yerini almıştır.

\section{BAHÇESARAY'IN MAHALLE TIPOLOJİSI}

Dinî faktörlerin mahallelerin ayrışmasında etkili olduğu yadsınamaz bir gerçektir. Nasıl ki Müslüman mahalleleri cami veya mescit merkezliyse, Yahudilerinki sinagog, Hristiyanlarınki ise kilise merkezlidir. Müslüman mahallelerinde cami veya mescit mahallenin merkezi bir kesimine yapılır hatta bazı mahalleler bu ibadethanelerin isimleri ile anılırdı. 1650-1675 tarihleri arasında Bahçesaray'da ismini bir ibadethaneden alan 10 mahalle tespit edilmiştir. Bunlar; Cami-i Kebir Mahallesi (Güneş 2006: 91-99), Koba Cami Mahallesi, Emir Celâl Mescidi Mahallesi, Hacı Ali Mescidi Mahallesi, Han Cami Mahallesi, Orta Cami Mahallesi, Mengli Giray Han Medresesi Mahallesi, Selim Giray Sultan Mescidi Mahallesi, Zaviye Mahallesi, Arslan Ağa Cami Mahallesi idi. Anadolu ve Rumeli şehirlerinde görülen bu şekilde isimlendirmelerin Bahçesaray mahallelerinde de uygulandığı anlaşılmaktadır. Örneğin Cami-i Kebir Mahallesi Anadolu'da hemen her şehirde karşılaşılan mahalle 
isimlerinin başında gelmektedir. Cuma camisinin bulunduğu bu mahalleye muhtemelen Kırım hanı Bahçesaray'da bulunduğu zaman her Cuma günü geliyordu. Çünkü bölgenin Cuma camisi buradaydı. Adı geçen mahalle 17. yüzyılda Bahçesaray'ın en büyük iki mahallesinden biriydi. Bu mahalle mahkeme tutanaklarında bazen Büyük Cami Mahallesi veya Cami-i Şerif Mahallesi adıyla da geçmektedir. "Kebir" büyük anlamına geldiğinden katipler kimi zaman büyük cami olarak kaydetmekte kimi zaman da cami-i şerif demektedirler. Sicillerde karşılaşılan mahallelerin katiplerin hataları göz önüne alınmadan farklı bir mahalleymiş gibi aksettirilmesi fahiş bir yanılgıya sebebiyet verebilmektedir. Kırım hanının yaşadığı sarayın bu mahallede olmasından dolayı diğer mahallelere kıyasla gayrimenkul fiyatları daha yüksekti. Zira, devlet görevlilerinin büyük bir kısmı yani askeri sınıf, zenginler ve büyük tüccarlar Cami-i Kebir Mahallesi'nin sakinleriydiler.

Kırım mahalle yapısını daha rasyonel bir yöntemle algılayabilmek adına Edrax-Max isimli mimarlık programı kullanılarak Bahçesaray'ın mahallelerinden Cami-i Kebir ve Koba Cami mahallelerinin mahkeme tutanaklarına yansıyan alım satım davalarından tahmini bir görüntüsü oluşturulmuştur. Amaç, mahallenin mekânsal özelliklerini analiz etmenin yanı sıra kimin kime komşu olduğu, yapıların düzenli bir şekilde mi yoksa gelişigüzel şekilde mi imar edildiği üzerine bir kanıya varmaktır. Buna göre yerleşim aşağıdaki gibidir:

\section{Görsel 1}

Cami-i Kebir Mahallesi

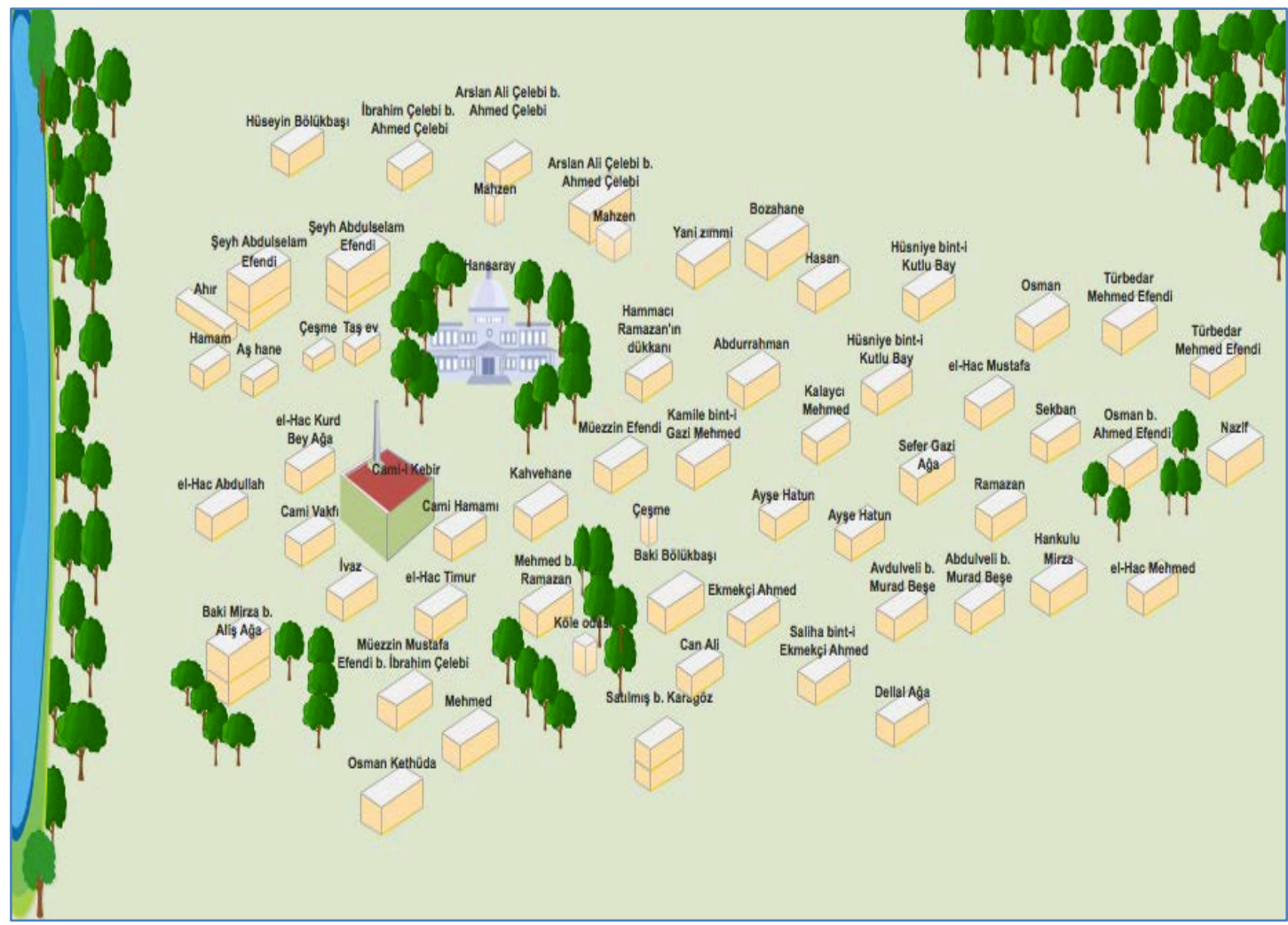

Cami-i Kebir Mahallesi'nin Bahçesaray şehrinin en büyük iki mahallesinden biri olduğunu belirtmiştik. Mahallenin büyüklüğü sadece mekânsal açıdan bir büyüklük değil aynı zamanda şehir nüfusunun yoğunlaştığı yerlerden biri olmasından dolayıdır. Nüfusun fazla olduğu yerlerde kişilerarası münasebetler artmakta; gayrimenkul alım satımı, 
sözleşmeler, adli vakalar, evlenme, boşanma gibi işlemler diğer bölgelere kıyasla daha fazla mahkemeye gelmekteydi. Mahalle sakinlerinden herhangi biri malını sattığında ya da bir yakınına hibe ettiğinde mahkemeye başvurarak ilgili satışı ya da hibeyi resmileştirme yolunu seçmekteydi. Aksi takdirde bir anlaşmazlık çıktığında mülkün kendisine ait olduğunu kanıtlayacak delili yoksa zor duruma düşebilirdi. Bu kayıtlardan satılan mülkün hangi gayrimenkullerden oluştuğunun yanı sıra etrafında nelerin bulunduğuna dair bazı bilgiler de elde edinilmektedir. Çünkü satış sözleşmelerinde ...'nın mülkü garben, şarken, şimalen ve kıbleten nereye baktığ 1 , kime komşu olduğu belirtilmekteydi. ${ }^{1}$

Görsele baktığımızda ilk dikkati çeken yapılar arasında hanın sarayı ve mahalle camisi bulunmaktadır. Bir vakıf yapısı olan cami, mahalleliyi bir araya getiren mekânların başında gelmekteydi. Tipik Osmanlı şehir anlayışında mahallede cami ve onun etrafında bir dizi vakıf binaları vardır. Yukarıdaki görselde de cami vakfına ait hamam, dükkân, çeşme gibi yapıların olması rastgele oluşmuş bir mekânlar topluluğu olmadığının göstergesidir. Mahalleliye hizmet veren bu yapılardan elde edilen gelir hem mahallenin bayındırlık faaliyetlerini sürdürmek hem de bu yapıların hizmet, tamir ve diğer masraflarını karşılamak için kullanılmaktadır (bk. KŞS 13, vr. 62).

Bahçesaray'ın bağlık bahçelik bir yer olmasında, görselde de görüldüğü üzere, Aşlama Nehri (Çürük Su) etkiliydi. Bu su, şehrin mahallelerinin büyük çoğunluğunun içinden geçtiğinden Bahçesaraylılar suya ulaşmakta sorun yaşamamaktaydılar. Evler ahşap malzemeden inşa edildiklerinden çok katlı evlere tek tük rastlanmaktaydı. Görselde de Şeyh Abdüsselam Efendi, Baki Mirza b. Aliş Mirza, Satılmış b. Karagöz'ün iki katlı (fevkani) evlere sahip oldukları görülmektedir. Şeyh Abdüsselam Efendi'nin varlıklı biri olduğu sahip olduğu yapılardan anlaşılmaktadır. Karşı karşıya iki katlı iki eve sahip olmasının dışında Abdüsselam Efendi'nin mülkleri arasında ahır, aşhane, hususi hamam, hususi çeşme ve taş malzemeden yapılmış bir evi vardı. Mahalledeki diğer yapılar incelendiğinde şeyh unvanlı bu efendinin mahallenin ileri gelenlerinden biri olduğu kanısına varılabilmektedir.

Klasik Osmanlı mahalle tiplemesinde öne çıkan ibadethane ve etrafındaki vakıf yapılar geleneği Cami-i Kebir Mahallesi'nde de görülmektedir. Caminin hemen yanında vakıf yapıları yer almaktadır. Vakıf dükkânları, medrese, mektep, kahvehane, bozahane, hamam gibi yapılar ve bunların konumlandığı yerler dikkat çekmektedir (Koç 2005: 168).

Görsel 1'de bozahane, mahallenin kuzey tarafında Yani adındaki bir gayrimüslimin evinin yakınında yer almaktadır. Mahallenin merkezinden oldukça uzak bir yerde bulunması ve gayrimüslim bir şahsın evine yakın olması bozahaneyi onun işlettiğini düşündürmektedir. Ayrıca bu durum Müslüman mahallesinde gayrimüslimlerin de oturduğunun bir göstergesi olarak değerlendirilebilir. Osmanlı şehirlerinde mahalleler her ne kadar etnik yapıya göre ayrışmı̧ olsalar da Müslümanlarla gayrimüslimler aynı mahallede yaşayabiliyor ve doğal olarak birbirleri ile komşuluk ilişkileri içine girebiliyorlardı (Yağcı-Genç 2013: 20).

Sosyal ortamın yapılarından olan kahvehane ise mahallenin orta kesimlerinde, vakıf yapılarına yakın bir yerdedir. Aynı şekilde tüm mahallelinin kullanabileceği umumi çeşmeler de vakıf yapılarına yakın yapılmıştır. Oluşturulan görselde Cami-i Kebir'e ait tespit edilen çeşme vakıf yapılarına yakınlığı ile dikkat çekmektedir. Kayıtlarda mahalleye ait bir

${ }^{1} \mathrm{Bu}$ görsel mahallenin sokaklarını içermemektedir. Kadı sicillerinde tespit edilen verilere dayanarak mekânsal analiz yapmak amaciyla oluşturulmuş tahmini bir görüntüdür. Mahallenin kesin bir görüntüsünü ortaya koyabilmek için daha detaylı bir kaynak türüne ihtiyaç vardır. Görsel oluşturulurken mahkeme tutanaklarında geçen şarken (doğu tarafi), garben (batı tarafi), şimalen (kuzey tarafi), kıbleten (güney tarafi) tabirleri mülkleri konumlandırmak açısından oldukça önemlidir. Örnek bir çalışma için bkz. (Sert 2008). 
çeşme tespit edilmesine karşılık Bahçesaray şehri genelinde çok fazla çeşme olduğu bilinmektedir. Çünkü çeşmelerin tamiri ile görevlendirilen bir işçiye günlük ne kadar ücret ödeneceği mahkeme kayıtlarına yansımıştır. ${ }^{2}$

Aşlama Nehri (Çürük su) mahalle halkının su ihtiyacını her ne kadar karşılasa da, tadı ekşi olduğundan, içme suyu olarak kullanılmamıştır (Evliya Çelebi 2003: 220) Bahçesinde su kuyusu olmayan mahalleliler uygun kaynaklardan çeşmelere verilen suyu içerlerdi. Şehirdeki çeşmeler, Evliya Çelebi'nin ilgisini çekmiş ve seyahatnamesinde Bahçesaray'da 70 adet çeşme olduğunu yazmıştır. Çeşmelerden akan suyun berrak ve soğuk olduğunu vurgulayan Evliya Çelebi, Temmuz ayında dahi bir adamın üç yudumdan fazla su içemeyeceğini ifade eder (Evliya Çelebi 2003: 220). Evliya Çelebi'nin yanı sıra Edward Daniel Clarke de çeşmelerden akan suyun soğuk, temiz ve kristal gibi olduğunu, sabahtan akşama kadar aktığını ve şehrin her kesiminde çeşme bulunduğunu belirtir. (Clarke 1811: 375).

Hane halkı ile birlikte yaşayan aileler sahip oldukları kölelerle bazen aynı evde yaşamak yerine onları barındıracakları yapıları da inşa ettiriyorlardı. Mehmed b. Ramazan'ın meyveli ve meyvesiz ağaçların bulunduğu (müsmire ve gayri müsmire) bahçesinde bir köle odası vardı. Sahip olduğu kölelerin kendi yaşam alanına yani mahremine girmesini muhtemelen tercih etmediği için onlara ayrı bir mekân yaptırmıştı. Ancak bir ikametgâh olarak köle odasının Bahçesaray mahallelerinde çok sık karşılaşılan bir yapı olmadığı görsel 1'den anlaşılmaktadır.

Bazı mahalleler ise her ne kadar ismini bir camiden ya da mescitten alsalar da içinde bulundurduğu farklı yapılarıyla ön plana çıkarlar. Koba Cami Mahallesi de bunlardan birisidir. Bu mahalle ticaretin yoğunlaştığı, Evliya Çelebi'nin de ifade ettiği gibi bir ucundan diğer ucuna kadar uzanan büyük bir çarşısı, dükkânları ve Kırım yarımadasının en büyük kervansarayı ile ön plana çıkmıştır.

${ }^{2} 1674$ tarihinin Mayıs ayının sonlarında Bahçesaray'daki çeşmelerin tamiri için Andriy adında bir gayrimüslimin çalıştırıldığı ve onarım için 3 akçe yevmiye verildiği kayıtlara geçmiştir (KŞS 20, vr. 75); Bahçesaray'da bulunan çeşmelerin tamirinde de ayrı bir listenin tutulduğu tespit edilmiştir (KŞS 10, vr. 52).

SEFAD, 2018 (39): 389-402 


\section{Görsel 2}

Koba Cami Mahallesi

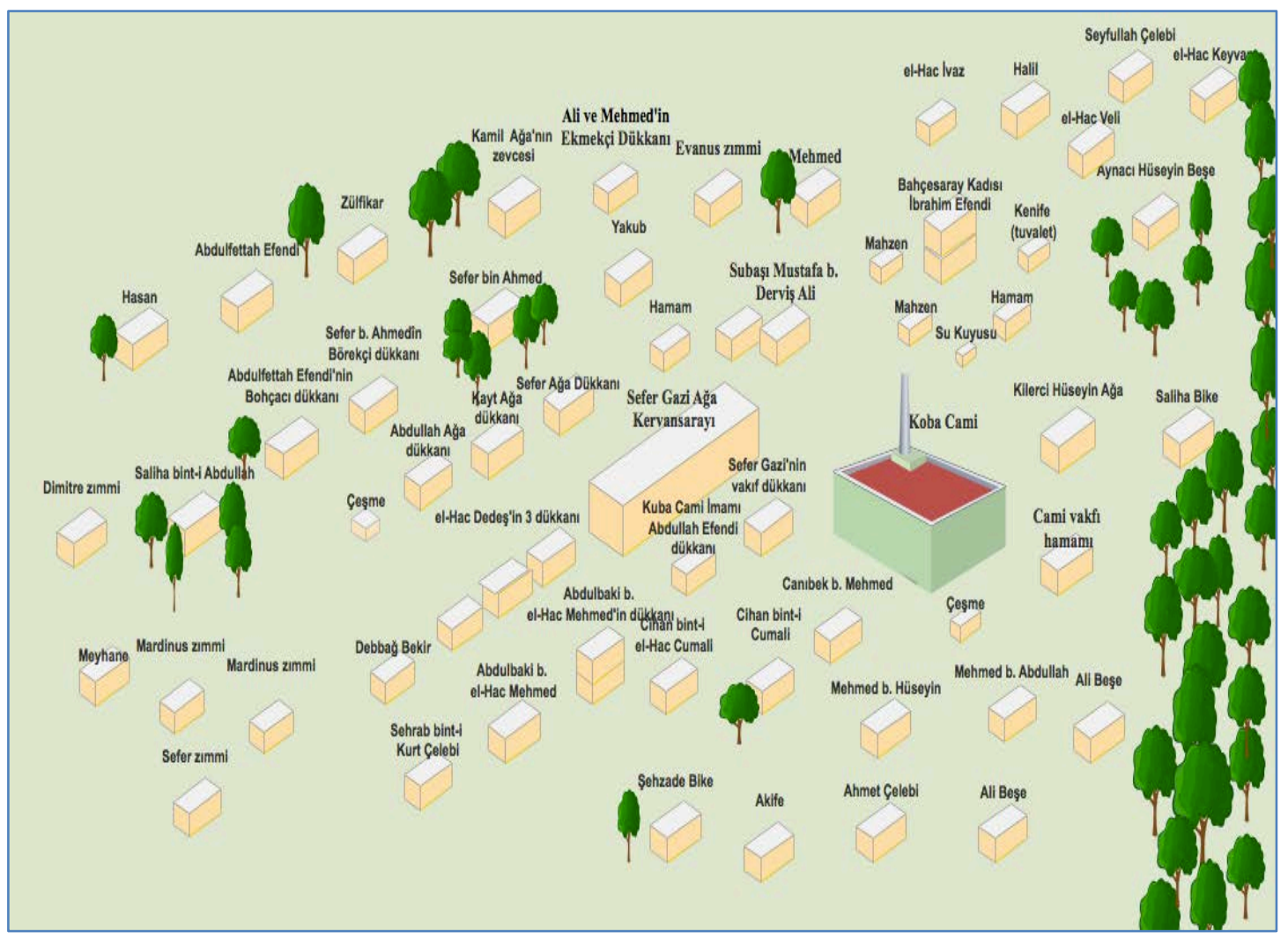

Görsel 2' de Cami-i Kebir Mahallesi'nde olduğu gibi Koba Cami'nin etrafında da vakıf yapıları vardır. Kervansarayın ve çarşının bu mahallede bulunması görselde görüldüğü üzere dükkânların kervansarayın hemen yanında yoğunlaşmasına neden olmuştur. Bohça, börek, ekmek dükkânlarının yanı sıra ne tür emtianın satıldığını tespit edemediğimiz dükkânlar da bulunmaktadır. Çünkü kadı sicillerinde sadece kime ait olduğu bilgisi kaydedildiğinden nelerin satıldığı konusunda fikir sahibi değiliz. Görsel 2'de cami vakfına ait yapılar mahalle sakinlerinin yanı sıra farklı memleketlerden gelen tüccarlara da hizmet sunmaktaydı. Mahalle sakinleri ve yaşadıkları evler incelendiğinde Bahçesaray kadısının bu mahallede ikamet ettiği, iki katlı (fevkani) bir evde yaşadığı anlaşılmaktadır. Kadının iki katlı evinin dışında bahçesinde iki adet mahzeni, tuvaleti (kenîf), hususi hamamı ve su kuyusu vardı. Kadı dışında mahallede yaşayan kişilerin unvanlarına bakıldığında çelebi, beşe, el-hâc, efendi, ăga gibi toplumsal olarak itibar edilen kişilerin yoğun olduğu anlaşılmaktadır. Bu mahalleyi Cami-i Kebir ile karşılaştırdığımızda gayrimüslimlerin daha fazla olduğu tespit edilmektedir. Mahallenin güney-batı kısmında gayrimüslimlerin yaşadığı ve evlerinin yanında bir meyhanenin de bulunduğu görülmektedir. Genel olarak her iki görsel göz önüne alındığında mahalleleri oluşturan yapıların gelişi güzel konumlandırılmadığı ve belli bir "form" da ihtiyaçlara cevap veren kendine özgü mekânlarını ürettiği söylenebilir.

İsmini bir cami ya da mescitten alan mahallelerin dışında şehrin ileri gelenlerinin adlarının verildiği mahalleler de Bahçesaray'da görülmekteydi. Anılan kişilerin sahip oldukları statü ve taşıdıkları unvan durumu açıkça ortaya koymaktadır. Sarraç, kâtib, terzi, humbaracı, bölükbaşı gibi mesleki kimlikleriyle tanınan şahısların isimlerinin mahallelere verilmesi ise sadece Kırım'a özgü bir durum değildir. Anadolu'nun hemen hemen tüm 
şehirlerinde benzer isimlere sahip mahalleler vardır. ${ }^{3}$ Bunlar; Sarraç Mustafa Mahallesi, Şahbolad Ağa Mahallesi, Bahadır Ağa Mahallesi, Kaytas Ağa Mahallesi, Ali Ağa Mahallesi, Hüseyin Ağa Mahallesi, Sehrab Efendi Mahallesi, Cemşid Efendi Mahallesi, Murtaza Ali Efendi Mahallesi, Kâtib Sefer Gazi Efendi Mahallesi, Hacı Hasan Efendi Mahallesi, Hacı Bekir Mahallesi, Hacı Cafer Mahallesi, Hacı Gazi Mahallesi, Hüseyin Bölükbaşı Mahallesi, Humbaracı Sefer Mahallesi, Ahmet Çelebi Mahallesi, Hacı Temir Mahallesi, Terzi Ali Mahallesi, Can Mehmed Mahallesi'dir.

İsminin yanında hacı, ağa, çelebi unvanı taşıyanlar kimliklerine değer atfedilen itibarlı kişilerdir. Bahsi geçen şahıslardan Bahçesaray toplumunda öne çıkanların isimlerinin mahallere verilmesi yaygindır. 1650-1675 tarihlerini kapsayan mahkeme tutanaklarından 20 mahallenin adını yerel ileri gelenlerden aldığı anlaşılmaktadır.

Farklı etnik unsurları bünyesinde barındıran Bahçesaray şehrinde genel anlamıla ayrışmış bir mahalle sistemi vardır. Her ne kadar Müslüman mahallesinde yaşayan farklı etnik kökenlerde kişiler varsa da bu durumun aksi pek görülmemektedir. Yani, Yahudi ya da Ermeni mahallesinde bir Müslüman'ın ikameti rastlanılan bir durum değildir. Mahallelerin oluşumunda kültürel kimlikler ön plana çıkmaktadır. Bahçesaray'da Müslümanların oturduğu mahalleler dışında gayrimüslimlerin oturduğu 7 mahalle tespit edilmiştir. Bunlar: Rum Mahallesi, Ermeni Mahallesi, Çingene Mahallesi, Çerkes Mahallesi, Rus Mahallesi, Çufutkale Mahallesi ${ }^{4}$ ve Boğdan Mahallesi'dir.

Ermeni, Yahudi ve Rum mahalleleri sakinleri hem etnik hem de dinî açıdan diğerlerinden farklıdır. Çünkü Çingene, Çerkes ve Boğdan mahallelerinde yaşayan ahalinin büyük çoğunluğu Müslüman'dır. Bu topluluklar İslâm dinini kendi kültürleri bağlamında yaşamaktadırlar. "Rus" veya "Urus" mahallesi olarak tutanaklara yansıyan mahallede Rusların yaşadığını düşünmek yanıltıcı olur. Muhtemelen mahalle ilk kurulduğunda ya Rusların ya da Rus asıllı azat edilmiş kölelerin yaşadığı bir mekândır. Sonrasında sadece Müslümanların ya da İslâm dinine geçmiş azatlı kölelerin yaşadığı bir mahalle hâline gelmiş olabilir.

Yukarıda mahallelerin mevcut isimlerini almalarında kurumlar, şahıslar ve etnik yapı faktörü üzerinde duruldu. Bu üç kategoriye uymayan adını yerleşimin dikkat çekici unsurlarından alan mahalleler de vardır. Şehreküstü Mahallesi, Debbağlar Mahallesi, Kuşçu Mahallesi, Dar Ağaç Mahallesi, Tarhan Mahallesi, Kuyu Önü Mahallesi ve Suvlu Koba Mahallesi tespit edilen mahalleler arasındadır.

Örneğin debbağ işiyle uğraşan kişilerin ve onların ailelerinin yaşadığı mahalle adını bu zanaatkâr zümreden almıştır. Dar a ̆ăç, kuyu önü, şehreküstü 5, suvlu koba gibi adlandırmalar ise yerleşim yerinin belirgin özelliklerinin mahalleye adını vermiş olduğunu göstermektedir. Suvlu Koba Mahallesi bunlardan birisi olup adını yerleşim yerinin sulu mağarasından

\footnotetext{
${ }^{3}$ Klasik dönem Osmanlı şehirlerinde mahalleler isimlerini dini ve vakıf yapılarından, cemaatlerden, bölgenin ileri gelenlerinden almaktaydılar. Osmanlı şehir tarihi çalışmalarının önde gelen tarihçilerinden biri olan Özer Ergenç'in Bursa, Ankara ve Konya şehirlerini ele alan çalışmaları tipik Osmanlı şehrinin mahalle isimlerini üzerinde oldukça açıklayıcı bir portre çizmektedir. İlgili çalışmalar için bk. (Ergenç 2014: 43-70; Ergenç 1995: 29-31, 44-47; Ze'evi 2000: 25-28; Maydaer 2009: 43-44; Taş 2004: 128-138; Açık 2012: 111-117).

${ }^{4}$ Yahudi mahallesidir, mahkeme tutanaklarında Kal'a (Kale) Yahudileri olarak geçmektedir.

${ }^{5}$ Şehreküstü, şehrin büyümesiyle nüfusun yerleşmesi amacıyla sonradan kurulmuş mahalleye verilen isimdir. Anadolu'nun birçok şehrinde bu isim ile mahalle bulunmaktadır (Öz 2005: 62). Şehre sonradan eklenen bir bölüm Şehreküstü (şehre küstü) adını almıştır. Bu isme XIV. yüzyıla kadar Anadolu'da rastlanılmamaktadır. Türkiye Selçukluları şehirlerinde ilgili isimde bir mahalle veya yerleşim adı görülmemektedir. Anadolu'da en erken tarihli örneği 1430'lu yıllarda Bursa'da tespit edilmiştir. Şehir nüfusunun artmasıyla o zamanlar dış bölgede yerleşime açılan mahalle "Şehre küstü" adını almıştır. Anadolu'nun birçok şehrinde ilgili isimle anılan mahalleler vardır (Baykara 1990: 130-131).
}

SEFAD, 2018 (39): 389-402 
almıştır. Yani, mahallenin bulunduğu coğrafyanın özelliği ve merkeze olan uzaklık isim verilmesinde önemli etkenler arasındadır.

1650 ile 1675 tarihleri arasında Bahçesaray şehrine ait mahkeme tutanaklarında 44 mahalle tespit edilmiştir. Ancak bu veriler sadece mahkemeye yansıyan davalardan tespit edildiğinden kesin bir sayı vermek mümkün görünmemektedir. Fehmi Yılmaz, Bahçesaray'ın Ocak 1784 tarihli nüfus sayımına göre şehrin 34 mahalleden oluştuğunu yazmıştır. ${ }^{6}$ Ancak vermiş olduğu veriler incelendiğinde sadece Müslüman mahallelerinin nüfusunun hesaplanıp kadı siciline kaydedildiği anlaşılmaktadır. Çünkü tespit edilen mahalle listesinde farklı etnik/dinî grupların yaşadıkları mahalleler göz önüne alınmadığından şehrin 100 yılı aşkın bir süre sonra 34 mahalleye düşmüş olması mümkün gözükmemektedir. Mahalle sakinlerinin göç ettirilmesi mahalle sayılarının azalmasına neden olmuş olabilir. Ömer Bıyık ise 1600-1774 yılları arasında Kırım'ı konu alan doktora tezinde Bahçesaray'ın 92 mahalleden meydana geldiğini tüm mahkeme tutanaklarını inceleyerek tespit etmiştir (Bıyık 2014: 132-135). Ancak aynı mahallenin mahkeme katipleri tarafından farklı isimlerde adlandırılması hususunu dikkate almadığından vermiş olduğu sayı oldukça fazla görünmektedir. Yukarıda da belirtildiği üzere Cami-i Kebir Mahallesi'nin büyük cami ve cami-i şerif gibi isimlendirmelerini göz önüne almaksızın ayrı birer mahalle olarak ele almıştır. 1600-1774 tarihleri arasında mahalle sayıları nüfusa paralel olarak artmıştır. Tüm bu veriler, incelediğimiz 1650 ile 1675 tarihleri arasında Bahçesaray'ın hâlâ gelişimini devam ettirdiği, ilerleyen zamanlarda yeni mahallelerin ortaya çıktığı ve sayısında artış meydana geldiğini göstermektedir.

Evliya Çelebi, Bahçesaray'ın mahallelerinden Han Cami, Sefer Gazi, Koba Cami ve İslam Ağa mahallelerinin isimlerini eserinde vererek şehrin en meşhur mahallelerinden olduklarını yazmaktadır (Evliya Çelebi 2003: 226). Bahsettiği mahallelerin kadı sicillerinde yer alması ve dönemin büyük mahallelerinden olması Evliya'nın Bahçesaray ile ilgili verdiği bilgilerin gerçeğe uygun olduğunu göstermektedir. Mahallede yaşayanlar açısından hane sayısı, Bahçesaray ile Anadolu'dan herhangi bir şehir karşılaştırıldığında çok çarpıcı bilgilerle karşılaşılmaktadır. Örneğin Anadolu şehirlerinden Edirne'nin büyük bir mahallesinde 59 hâne olmasına karşın 172 ailenin bahsi geçen mahallede ikamet ettiği ve hatta bir hânede 5 ile 8 ailenin birlikte yaşadığı ifade edilmektedir (Uğur 2015: 68). Böyle bir durum Bahçesaray'ın mahallelerinde pek görülmemektedir.

\section{BAHÇESARAY'IN KONUT TIPOLOJİSI}

Yaşanılan mekânlar toplumu ve kültürü anlamak adına araştırmacılara çeşitli bilgiler verir. Çünkü onların da bir dili vardır, konuşturmasını bilene inşa edenin zihniyeti, yaşam tarzı ve inancı hakkında bilgiler sunar. Mekânın özellikleri, kapladığı alan, bulunduğu semt, yapıldığı malzemeler sahibinin ekonomik durumuna dair zihinlerde bir kanaatin oluşmasını sağlar. Mahkemeye gelen mülk davalarından Bahçesaraylı ev sahiplerinin yaşadıkları evlerin fiziki özellikleri, alımı veya satışı gerçekleşen gayrimenkullerin fiyatları, evlerin dışında bulunan diğer yapıların neler oldukları öğrenilebilmektedir. Öncelikle mekânsal yapıyı anlayabilmenin yolu mahkeme kayıtlarında gayrimenkuller için kullanılan terminolojiyi çözümlemekten geçmektedir. Kırım Hanlığı kadı sicillerinde evler ve evlerin

${ }_{6}^{6} 1784$ tarihli nüfus sayımında tespit edilen mahalleler için bk. Han Cami, Saksağan (Sağuskan), Kaytas Ağa, S,ehreküstü, Sarı Hüseyin, Kadı, Abid Efendi, Ömerşah Efendi, Asmakuyu, Arslan Ağa, Molla Mustafa, Debbağhane, Mektum, Sulu Koba, Meliş Ağa, S,ehrinüstü, Șah Bolat Ağa, Büyük Aktaş, Salaçık, Şaban Molla, Orta Cami, Hacı Gök, Osman Ağa, Sincan, Kozoğlu Kızı(?), Eskiyurt, Mahzar Efendi, Akçokrak, Yukarı Medrese, Yukarı Mescid, Yeșil Cami, Orta Medrese, Baba Kurt, el-Hâc Ali Ağa (Yılmaz 2015: 181). 
etrafını çevreleyen yapılar tarif edilirken mülk, dâr, bâb, çit hâne, çatma hâne, taş hâne, tahtânî, fevkânî, mahzen, kiler, müsmire ve gayr-i müsmire, muttasıl, muhavvata, yurt, hayat, havale, ahır, bi'r-i mâ̂, kenifî, sayfiye, buyut-u müteaddide, târîk-i âmm, târîk-i has gibi kavramlar kullanılmıştır.

Mülk kavramı, genellikle mahkeme kayıtlarında bir gayrimenkulün dört tarafında yer alan komşularını belirtir. Mülkten kastedilen yapının ev mi bağ, bahçe mi olduğu tam olarak anlaşılmamakta, bir gayrimenkulün alımı veya satışı gerçekleştiğinde etrafında yer alan komşuları şarken, garben, kıbleten, şimalen ...'nın mülkü şeklinde kayıtlarda geçmektedir. Suraiya Faroqhi'nin de "Orta Halli Osmanlılar" adlı eserinde belirttiği gibi bir mahallede bulunan arazilerin çoğunun üzerinde ev vardır ve bu terim, evlerle birlikte yer alan tüm yapıları kapsayan kavram olarak kullanılmıştır (Faroqhi 2009: 8). Bu bağlamda mülk ile dâr kelimeleri benzerlik göstermektedirler. Sözlükte "yer" anlamında kullanılan dâr kelimesinin7, bir dizi yapının kapladığı alanı ifade ettiği sicillerden anlaşılmaktadır. Örneğin "bir kıt'a mülkim olan dârım dâhilinde bir bâb çatma ve taş hâne müştemilidir cümle tevâbî ve levâhıkıyla ve hukûk-u murâfîk ve eşcâr-ı müsmire ve gayr-i müsmiresiyle" şeklindeki tanımlama bir dizi yapıya işaret eder (KŞS 13, vr. 29). Mülkün, sahip olunan tüm gayrimenkuller, dârın ise sadece arazi (yer) olduğu göz önüne alındığında ...'nın mülkü tabirinin ayrıntıdan uzak bir tanımlama olduğu görülmektedir.

Sözlüklerde bir anlamı da kapı olan bâb kelimesinin (Doğan 2011: 133) belgelerde bir bâb oda, üç bâb çatma hâne şeklinde geçmesi söz konusu kelimenin odayı ve kapıyı içine alan bir mülk kavramı olduğu kadar evi de ifade ettiği (üç bâb tahtanî alt katta üç oda, iki bâb fevkanî üst katta iki oda) anlaşılmaktadır. Yaşanılan eve doğrudan atıfta bulunan kelimeler çatma hâne, taş hâne ve çit hânedir. Evlerin yapıldıkları malzemeye göre bu isimleri aldıkları açıtır. Çatma hâne ahşaptan, çit hâne saman, kamış, çalı gibi malzemelerin çamur ile yoğrulmasından, taş hâne ise taş malzeme kullanılarak inşa edilen konutları ifade eder. Ev tek katlıysa tahtanî, iki katlıysa fevkanî kelimesiyle belgelerde belirtilir (Kuban 1995: 51; Faroqhi 2009: 115). Bahçesaray başta olmak üzere neredeyse tüm Kırım şehirlerinde evlerin ve dükkânların ya yanlarında ya da altlarında mahzenleri ${ }^{8}$ vardır. Kömürlük gibi kullanıldığı düşünülen mahzenlerde bazen değerli malların da saklandığı kadı sicillerinde görülmektedir. Özellikle dükkânların altlarında bulunan mahzenlerde satışı yapılacak ürünler de muhafaza edilmektedir (KŞS 4, vr. 52; KŞS 13, vr. 3; KŞS 20, vr. 9, 69, 86). Mahzen bu yönüyle kilerden farklıdır. Kiler içerisinde yiyeceklerin saklandığı odadır ve incelenen kayıtlarda evin içerisinde bir oda olmayıp dışarıda yer almaktadır (KŞS 17, vr. 28). Eşcâr-ı müsmire ve gayr-i müsmire ise evin etrafında bulunan meyveli ve meyvesiz ağaçları tanımlayan bir kavramdır (Açık 2010: 219). Bir konutun hemen yanındaki diğer konutlar dizisi muttasıl, duvarlarla çevrili olanlar muhavvata kelimesi ile tarif edilmektedir (Kuban 1995: 48).

Bahçesaray'da evlerin bazılarının yurt kelimesiyle ifade edildiği görülmektedir. Kuban, söz konusu kelimenin göçer konutun en iyi örneği olarak yurt'u nitelediğini vurgulamaktadır (Kuban 1995: 38). Kırım'da 17. yüzyılda bile göçebe kültürün etkisini hissettirdiğini göstermesi açısından yurt kavramı oldukça önemlidir. Kırımlıların yayla ve kışlalarındaki evleri sicillere yansıdığında yaşanılan yer, yurt şeklinde evlerini tarif ettikleri düşünülmektedir. Yerleşim birimlerinin isimlerinde de "Eskiyurt, Yurt" kavramlarını kullandıkları görülmektedir. Mahkeme kayıtlarındaki gayrimenkul terminolojisinde hayat

7 Yer, ev, bina, yapı ve mekânı ifade etmektedir (Doğan 2011: 346).

8 Çeşitli malları korumak ve koymak amacıyla kullanılan yer altı deposudur (Doğan 2011: 1146).

SEFAD, 2018 (39): 389-402 
ibaresi sıklıkla geçmektedir. Bu kelimeyle kastedilen evin odaları ve kapalı mekânları değil bahçe veya avlu gibi açık alanlarıdır (Faroqhi 2009: 84). Bahçesi olan evlerde kadınların evin bahçesinde geçirdiği süre boyunca dışarıdan görülmemesi için havale (Doğan 2011: 717) adı verilen perde gibi bir duvar örülerek mahremiyet korunmaktadır. Yazın gezilecek, yaşanılacak yer olarak sözlüklerde geçen sayfiye (Doğan 2011: 1485) de Bahçesaraylıların evlerinin dışındaki mekânı ifade etmektedir. Bazen kadı sicillerinde oda, sofa, tabhâne ayrı ayr1 yazılmayıp buyut-u müteaddide (bir dizi yapı) denmektedir (Faroqhi 2009: 85). Evin dışında bulunan diğer yapılar ise ahır, bi'r-i mầ (su kuyusu) ve kenif yani helâdır. Son olarak, gayrimenkul terminolojisinde herkesin kullanımına açık, yol anlamına gelen tarîk-i âmm ve sadece bazı kişilerin geçme hakkı bulunan yol anlamında tarîk-i hâs terimleri sıkça geçer (Açık-Düzenli 2015: 246; Faroqhi 2009: 50).

Bahçesaray evlerinin büyük çoğunluğunda ahşap malzeme kullanılmış olduğu mülk kayıtlarında açıkça görülmektedir. Şehrin ormanlık bir sahada kurulması, etrafının bağlık ve bahçelik olması konut malzemesini doğrudan etkilemiştir. Ahşap malzemeden sonra en çok saman, kamış gibi otların çamur ile sıvanmasıyla inşa edilen çit hâne isimli evlerin kullanıldığ 1 tespit edilmektedir. Martin Bronevskiy'in [Marcin Broniewski], konut mimarisi hakkındaki gözlemleri Bahçesaray'ın XVI. yüzyıldaki ev tipolojisini gözler önüne sermektedir. Martin Bronevskiy Bahçesaray'da taş malzemeden yapılmış sadece bir evin bulunduğu ve onda da Kırım hanının yaşadığını vurgulamaktadır (Bronevskiy 1970: 24). 16. yüzyılda kurulan Bahçesaray'ın ilk yerleşimlerinde konutların ahşap ve kerpiçten yapıldığ anlaşılmaktadır. Edward Daniel Clarke'de evlerin ahşap ve pişmiş tuğladan yapıldığına, çatılarında kırmızı kiremitler bulunduğuna dikkat çekmektedir (Clarke 1811: 390).

Şehrin sakinlerinin hemen hepsinin kendilerine ait bir evi olduğu, kirada oturmadıkları anlaşılmaktadır. Evlerin fiyatları, yapıldığı malzeme, sahip olduğu oda sayısı, genişliği, tek/çift kat olması, bahçesi, su kuyusu, ahırı, tuvaleti, aş hanesi olup olmadığı ve bulunduğu mahalleye göre değişmektedir. Bahçesaraylı zenginler müreffeh evlerde yaşamakta ve oturdukları mahallelinin kullandığı umumi mekânları kullanmamaktadır. Koba Cami Mahallesi'nde Ümmi Gülsüm Bike'ye hibe edilen 1.200 kuruş (700 altın) değerindeki iki katlı iki evin, önünde yazın gezilecek geniş alanı, büyük bir avlusu, hamamı, su kuyusu ve helâsı olduğu bilinmektedir (KŞS 20, vr. 84). Evlerin iki katlı olması dayanıklı malzeme gerektirdiğinden taştan yapıldığı düşünülmektedir. Su kuyusuna sahip olan evlerin fiyatının yüksek olması tesadüf değildir. Abdullah kızı Dellale Benefşe, Ermeni Mahallesi'nde bir çatma ve bir çit evini, su kuyusu, meyveli ve meyvesiz ağaçlarıyla Giragoz isimli Ermeni'ye 190 kuruşa satmıştır (KŞS 20, vr. 68). Benefşe'nin baba adının Abdullah olarak yazılması kendisinin de din değiştirip Müslüman olduğunu ve bu sebeple de Ermeni mahallesinden taşınıp Müslümanların oturduğu bir semte yerleşmek için gayrimenkullerini sattığını düşündürmektedir. Koba Cami Mahallesi'nden el-Hâc Dedeş'in satılığa çıkardığı mülkü, iki odalı bir evdir. Ancak evin önünde geniş bir alan, bahçesinde iki oda, odaların altlarında birer mahzen, meyveli ve meyvesiz ağaçlar ile bahçenin dışarıdan görülmesini engelleyen taştan yapılmış havalesi vardır. Pazar değeri 300 kuruş (200 altın) olan bu evi elHâc Şahin isimli adam satın almıştır (KŞS 21, vr. 10). Ev fiyatlarını mekanın büyüklüğü ve sahip olduğu özellikler etkilemektedir. Çünkü aynı mahallede daha düşük piyasa fiyatı bulunan gayrimenkuller de bulunmaktaydı Ancak bu konutlar zenginlik göstergesi sayılabilecek konut tipolojisine uymamaktadır. Örneğin Ahmet kızı Saliha'nın bir odalı evi (çit hâne) meyveli ve meyvesiz ağaçlarıyla birlikte 30 kuruşa (20 altın) satılmıştır (KŞS 9, vr. 5). Orta halli kişilerin evlerinin piyasa değerinin 20-100 kuruş arasında değiştiği kadı 
sicillerinden tespit edilebilmektedir. Genelde sağlam malzemeden yapılan taş evlerde zenginler ve kısmen orta halli kişiler otururken, fakirler ise ahşap ve kerpiç evlerde yaşamaktadırlar. Buradan hareketle coğrafyanın insanlara sunduğu malzemenin konut yapımında etkili olduğu söylenebilir. Fakirlerin daha kolay tedarik edebildiği geçici malzemeden ev yapmaları bununla ilişkilidir. Oysa taş malzeme, ahşap ve kerpiç malzemeye nispeten çok daha zor tedarik edilmekte ve daha fazla iş yükü gerektirmektedir. Başka bir deyişle kalıcı (taş) malzeme bir nevi zenginliği çağrıştırmaktadır. Bu durum Turgut Cansever'in ileri sürdüğü düşünce ile çelişmektedir. Öyle ki Cansever, Osmanlı insanının zihnindeki dünyanın geçiciliğinden dolayı geçici malzeme, buna karşılık Avrupalıların dünyaya tamahlarından dolayı da kalıcı (taş) malzemeden evlerini inşa ettiklerini ifade ederek inanç faktörüne vurgu yapar (Cansever 1996: 129-130). Dinin, mimari yapıya etkisi yadsınamaz bir gerçektir. Fakat söz konusu durumu tek bir nedenle açıklamak oldukça güçtür. Coğrafyanın insana sunduğu temel yapı malzemeleri, daha güvenli ve sağlam evlerde yaşama isteği, zenginlik gibi faktörlerin de etkili olduğu söylenebilir.

Evlerin değerini belirleyen tek etmen, yapıldı̆̆ı malzeme değildir. Yapının bulunduğu konum, büyüklük, sahip olduğu eklemler de evin piyasa değerini artırır. Örneğin; Çingene Mahallesi sakinlerinden Hasan'ın ahşap evi, meyveli ve meyvesiz ağaçlarıyla 20 altın değerinden alıcı bulmuştur (KŞS 9, vr. 22). Eve eklenen diğer mekânlar fiyatı yükseltmektedir. Terzi Ali Mahallesi'nde Derviş Ali oğlu Arslan'ın sattığı bir odası ve avlusu bulunan iki evinin değeri 49 altındır. (KŞS 19, vr. 51). Evin iki katlı olması, yanında su kuyusu bulunması piyasa değerini hayli yükseltmektedir. Arslan Ağa Mahallesi'nden Gülşah'ın, iki katlı ve iki odası bulunan evi, yanında misafir hanesi ve kuyusuyla birlikte 100 kuruşa satılması örnek olarak gösterilebilir. (KŞS 20, vr. 69). Konuta fırın, aşhane, kiler, mahzen, ahır, çeşme, hamam gibi yapıların eklenmesi fiyatların artmasında etkili olmuştur. ${ }^{9}$

\section{SONUÇ}

$\mathrm{Bu}$ çalışmada 1650-1675 tarihleri arasında Bahçesaray şehrinin kadı sicillerine yansıyan kayıtları üzerinden çeşitli yönleriyle mahalle yapıları ve ev tipolojileri ortaya konulmuştur. Osmanlı şehrini oluşturan mahalle ve konut tipolojisinin bir benzerinin Kırım'da görüldüğü anlaşılmıştır. Edraw-Max isimli mimarlık programı yardımıyla şehrin iki mahallesi üzerinden yapılan değerlendirmelerde yapıların rastgele inşa edilmediği ve mahallenin bir düzeni olduğuna işaret edilmiştir. Hanın sarayının bulunduğu Cami-i Kebir Mahallesi ve ticari yapıların yer aldığı Koba Cami Mahallesi toplumun elit sayılabilecek kesiminin oturduğu yerlerdir. Diğer mahallelerde toplumun elit sayılabilecek kesimleri ile orta halli insanların bir arada yaşadığı bilinirken söz konusu mahallelerde üst düzey görevliler ve varlıklı aileler yaşadığı anlaşılmıştır.

\footnotetext{
${ }_{9}$ Örnek ev tipleri ve fiyatlarına bk. Cami-i Kebir Mahallesi'nden Ayşe'nin karşı karşıya iki ahşap evi avlusuyla 90 altına (KŞS 9, vr. 44), Rum Mahallesi'nden Balan Karkan ve Hacı Ali adındaki tüccarların sattıkları ev 130 kuruş (KŞS 9, vr. 87), Debbağ Mahallesi imamı Derviş Molla Akay'ın Salaçı'ta küçük bir evi, yanında bahçesi, meyveli ve meyvesiz ağaçlarıyla 83 altın (KŞS 9, vr. 90), Cami-i Kebir Mahallesi'nden Baki Mirza'nın iki katlı, üç odalı evi, meyveli ve meyvesiz ağaçlarıyla 120 kuruş (KŞS 10, vr. 84), Humbaracı Sefer Mahallesi'nde el-Hâc Mehmed kızı Huri'nin satın aldığı ahşap ev, çit avlusu ile 130 kuruş (KŞS 11, vr. 68), Suvlu Koba Mahallesi'nde Raziye'nin sattığı iki ahşap ev, kerpiç ve taştan yapılmış mahzenler, yanında bir miktar arazi ve havalesiyle 200 kuruş (KŞS 13, vr. 41), Cennet Han Bikeç'in iki ahşap evi, her birinin altında mahzen, bir ahşap aşhane, bir sobalı taş ev, bir ahşap oda, taştan yapılmış ahır, bir taş hamam, çeşme, büyük bir avlu ve yanında kışla ile 650 kuruş (KŞS 13, vr. 62), Çufutkale'de Moşe oğlu Yasef'in ahşap ev, mahzen ve avlusuyla 140 kuruş (KŞS 16, vr. 37), yine Çufutkale'de Semha oğlu Yasef'in sattığı bir ahşap ev, iki taş ev, mahzen ve avlu ve taş havalesiyle 300 kuruş (KŞS 16, vr. 56), Koba Cami Mahallesi'nde Saliha Bike'nin iki ev ve bir aşhanesi 197.5 kuruştur (KŞS 20, vr. 83).
}

SEFAD, 2018 (39): 389-402 
Bahçesaray'da evlerin bir, iki veya en fazla üç odalı olduğu, ahırı, kiler, aşhane, helâ, hamam gibi yapıların evin dışında yapıldığı, mahzenlerin ise genelde konutun ya altında ya da diğer yapılarla birlikte evin dışında olduğu tespit edilmiştir. Örnekler incelendiğinde ahşap evlerin daha fazla olduğu görülmüştür. Dükkanlar ve vakıf yapıların kiralara verildiği bilindiği halde kayıtlarda evlerin kiraya verildiğine dair bir veriye rastlanmamıştır.

\section{SUMMARY}

Neighbourhood and house typology have been the topic of many studies in Ottoman urban historiography. Although historians have produced plenty of studies, mostly articles, relating to neighborhood typology with the aim of providing a theoretical basis, few of them provide an adequate new approach. This study offers a new method of analyzing neighborhood structures and house typology, demonstrated on the basis of Bakhchisaray for the period 1650-1675. Using the Edraw-Max architectural software, we have been able to generate some visual estimates by processing data obtained from the Bakhchisaray qadi court registers (sicils). The first step of our method is to locate sicil-records of immovable property sales, most often for houses. Thereupon neighborhood images are created on the basis of information on buildings adjacent to buildings that are the subject of a sale. In this way, we are able to address questions such as who was the neighbour of whom, whether a house or other building was constructed in a regular or haphazard manner and what were the physical characteristics of the relevant structures. In addition, we can assess whether or not elite and ordinary people lived in the same neighbourhood.

Assessments have been made on two neighbourhoods of Bakhchisaray that frequently occur in the court registers-Cami-i Kebir and Koba Cami. Of particular interest is visualizing the Cami-i Kebir neighbourhood, since the palace where Crimean Khan lived was located in this neighbourhood. The other neighbourhood visualization is of interest because it had the largest bazaar of the city, as well as many shops, inns and a large caravanserai. While the former neighbourhood was mostly administrative, the latter was more commercial. The core of this study relates to the structural features of these neighbourhoods.

By analyzing archival data and on this basis reviewing recent studies, we indicate some differences and similarities between Ottoman and Crimean neighbourhoods. We also endeavor to help understand which factors determined houses prices-features such as the main material of these buildings, their sizes, additional parts (kitchen, bath, toilet, garden, courtyard, cellar, barn), whether single or two storey, water resources, proximity to smaller markets or larger bazaars. Thereby, it is possible to arrive at a house typology for Bakhchisaray. 


\section{KAYNAKÇA}

Abacı, Nurcan (2005). "Osmanlı Kentlerinde Sosyal Kontrol: Araçlar ve İşleyiş". Şinasi Tekin'in Anisina Uygurlardan Osmanliya: 101-111.

Açık, Turan (2010). “Bir Yeniden İnşa Denemesi: 18. Yüzyılın Ortalarında Trabzon Evleri Hakkında Bazı Tespitler". Trabzon Kent Mirası Yer-Yapı-Hafiza. ed. Ömer İskender Tuluk, Halil İbrahim Düzenli. İstanbul: Klasik Yay. 215-236.

Açık, Turan (2012). Gelenek ve Modernlik Arasında Bir Osmanlı Şehri: 17. Yüzyılın Illk Yarısında Trabzon'da Siyaset. Doktora Tezi. Trabzon: Karadeniz Teknik Ü.

Açık, Turan-Düzenli, Halil İbrahim (2015). "XVI-XVII. Yüzyıl İstanbul Evlerine Dair". Antik Çă̆'dan XXI. Yüzyıla Büyük İstanbul Tarihi. ed. Coşkun Yılmaz. İstanbul: İSAM Yay. 244248.

Baykara, Tuncer (1990). Anadolu'nun Selçuklular Devrindeki Sosyal ve İktisadi Tarihi Üzerine Araştırmalar. İzmir: Ege Üniversitesi Edebiyat Fakültesi Yay.

Bıyık, Ömer (2014). Kırım'ın İdarî ve Sosyo-Ekonomik Tarihi (1600-1774). İstanbul: Ötüken Yay.

Bronevskiy, Martin [Marcin Broniewski] (1970). Kırım. çev. Kemal Ortaylı. Ankara: Ege Matbaası.

Cansever, Turgut (1996). “İslam Mimarîsi Üzerine Düşünceler”. Divan (1): 119-146.

Clarke, Edward Daniel (1811). Travels in Various Countries of Europe, Asia and Africa. London: Lorence Press.

Çetin, Cemal (2016). “Osmanlı Toplumunda 'Seyirci Etkisi' Üzerine Bazı Gözlemler (16001750)". International New Tendencies Congress in Ottoman Researches: 127-143.

Doğan, Mehmed (2011). Büyük Türkçe Sözlük. Ankara: Yazar Yay.

Eldem, Ethem-Goffman, Daniel vd. (2012). Doğu ile Batı Arasında Osmanlı Kenti Halep, İzmir ve İstanbul. çev. Sermet Yalçın. İstanbul: Türkiye İş Bankası Kültür Yay.

Ergenç, Özer (1984). “Osmanlı Şehrindeki Mahalle'nin İşlev ve Nitelikleri Üzerine”. Osmanlı Araştırmaları (4): 69-78.

Ergenç, Özer (1995). Osmanlı Klasik Dönemi Kent Tarihçiliğine Katkı XVI. Yüzyılda Ankara ve Konya. Ankara: Ankara Enstitüsü Vakfı Yay.

Ergenç, Özer (2014). XVI. Yüzyıl Sonlarında Bursa. Ankara: Türk Tarih Kurumu Yay.

Evliya Çelebi (2003). Evliya Çelebi Seyahatnamesi Topkapı Sarayı Kütüphanesi Bağdat 308 Numaralı Yazmanın Transkripsiyonu-Dizini. haz. Y. Dağlı, R. Dankoff, 7. Kitap. İstanbul: Yap1 Kredi Yay.

Faroqhi, Suraiya (2009). Orta Halli Osmanlılar. çev. Hamit Çalışkan. İstanbul: Türkiye İş Bankası Yay.

Güneş, Hasan Hüseyin (2006). "Bahçesaray Câmi-i Kebir Mahallesi İnsanlar ve Kurumlar". Karadeniz Araştırmaları (11): 91-99.

Kançal-Ferrari, Nicole (1997). "Han Sarayı". DİA, C. 15: 521-524.

Kançal-Ferrari, Nicole (2005). Kırım'dan Kalan Miras Hansaray. İstanbul: Klasik Yay.

Kırım Şer'iyye Sicilleri, Fond 917 (KŞS): 4, 9, 10, 11, 13, 16, 17, 19, 20, 21.

Koç, Yunus (2005). “Osmanlı'da Kent İskânı ve Demografisi (XV.-XVIII. Yüzyıllar)". TALİD 3 (6): 161-210.

Kuban, Doğan (1978). “Anadolu-Türk Şehri Tarihi Gelişmesi, Sosyal ve Fiziki Özellikleri Üzerine Bazı Gelişmeler". Vakıflar Dergisi (7): 53-73.

Kuban, Doğan (1995). Türk Hayat'lı Evi. İstanbul: Eren Yay.

Leeuwen, Richard Van (2012). Bir Osmanlı Şehri Şam: Vakıflar ve Şehir. çev. H. Ebru Aksoy. İstanbul: Küre Yay.

SEFAD, 2018 (39): 389-402 
Maydaer, Saadet (2009). Osmanlı Klasik Döneminde Bursa'da Bir Semt Hisar. Bursa: Emin Yay. Ortaylı, İlber (2008). Türkiye Teşkilât ve İdare Tarihi. Ankara: Cedit Neşriyat.

Öz, Mehmet (2005). “Osmanlı Klasik Döneminde Anadolu Kentleri”. TALID 3 (6): 57-88.

Özvar, Erol, Arif Bilgin (2008). Selçuklulardan Cumhuriyete Şehir Yönetimi. İstanbul: Türkiye Dünyası Belediyeler Birliği.

Sert, Özlem (2008). Reconstructing a Town from its Court Records Rodosçuk (1546-1553).

München: Dissertation an der Fakultät für Kulturwissenschaften der LudwigMaximilians Universität, Doktora Tezi.

Taş, Hülya (2004). XVII. Yüzyılda Ankara. Doktora Tezi. Ankara: Ankara Ü.

Uğur, Yunus (2015). “Mahalle Biyografilerine Bir Katkı: Osmanlı Dönemi Edirne'sinden Dört Örnek". Şehir\&Toplum (3): 63-73.

Weber, Max (2010). Şehir. çev. Musa Ceylan. İstanbul: Bakış Kitaplı̆̆ı.

Yağcı, Zübeyde Güneş, GENÇ, Serdar (2013). H.1256/M. 1840-41 Tarihli Balıkesir Nüfus Defteri (Değerlendirme ve Transkripsiyon). Balıkesir: Balıkesir Belediyesi Kent Arşivi Yay.

Yaşa, Firat (2017). Bahçesaray (1650-1675). Doktora Tezi. Sakarya: Sakarya Ü.

Yılmaz, Fehmi (2015). "XVIII. Asırda Hanlık Başkenti Bahçesaray". Doğu Avrupa Türk Mirasının Son Kalesi Kırım. ed. Yücel Öztürk. İstanbul: Çamlıca Yay. 179-215.

Ze'evi, Dror (2000). Kudüs 17. Yüzyılda Bir Osmanlı Sancağında Toplum ve Ekonomi. çev. Serpil Çağlayan. İstanbul: Tarih Vakfı Yurt Yay. 